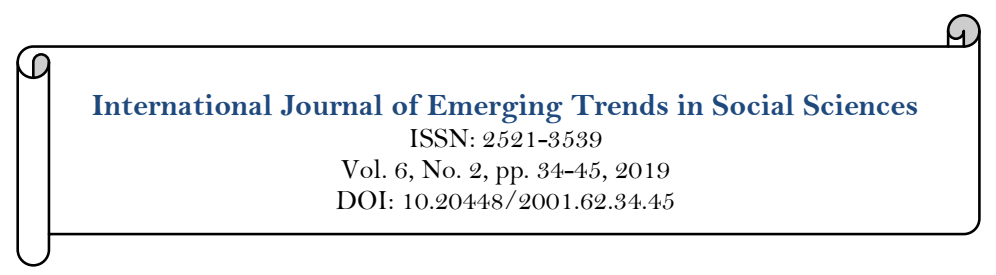

\title{
Environmentally Sustainable Supply Chain Practices, Organisation Culture on Firm Performance. A Mediation Approach
}

\author{
Zurah Chepkoech Mohammed $^{1^{2}}$ \\ Vincent Ngeno ${ }^{2}$ \\ Charles Lagat ${ }^{3}$
}

'Lecturer, School of Business and Economics, Department of Management Science, Moi University, Kenya.

Email:mohammedzurah@yahoo.com

${ }^{2}$ Lecturer, Moi University, Department of Agricultural Economics and Resource Management, Moi University, Kenya.

${ }^{3}$ Associate Professor, Moi University, Department of Marketing and Logistics, Moi University, Kenya.

\section{Abstract}

Sustainability is increasingly turning into a strategic business project that firms are recognizing that sustainable carry outs can be economical and ought to make fresh income streams as well as enhance client and worker gratification. Despite this, sustainability and performance of firms have received little research attention. Using Natural Resource-Based View and stakeholder theory, research main purpose was to determine the mediating effect of organization culture on the association amid environmentally sustainable supply chain practices and firm performance. This study used descriptive statistics, Pearson product-moment correlation, and Structural Equation Modeling (SEM) to test the hypothesis. Data collected from 281 Kenyan manufacturing firms were used to test study hypotheses. From biascorrected bootstrapping Structural Equation Modeling, results showed that organization culture variable fully mediates the association amid environmentally maintainable supply chain methods on the performance of manufacturing firms. Thus, the study infers that a strong organizational culture in the organization leads to the enhanced implementation of environmentally sustainable supply chain practices in the organization which in turn increases the performance of manufacturing firms. Without organization culture, these practices may go unheeded and not contribute to improved performance of manufacturing firms in Kenya. Consequently, this study recommends that the managers of these firms should build an organizational culture with environmental concerns in all their processes. This study hence contributes to theory and practice by the inclusion of organizational culture and also extends natural resource-based view and stakeholder theories of a firm.
Keywords:

Environmentally

Sustainable supply chain practices

Organisation culture

Firm performance.

Licensed:

This work is licensed under a

Creative Commons Attribution 4.0

License.

Publisher:

Scientific Publishing Institute

Accepted: 10 October 2019

Published: 30 October 2019

Funding: This study received no specific financial support.

Competing Interests: The authors declare that they have no competing interests.

\section{Introduction}

In today's internationally competitive surroundings, assessing performance is commonly considered to be an important component of effective preparation, control, and decision-making (Ahi \& Searcy, 2015). Naslund and Williamson (2010) proposed that in the competitive worldwide surrounding, the performance of a firm can no lengthier only be established by the choices and activities that take place inside a company; rather it will rely on the implementation of choices and activities engaged in its whole supply chain. Pullman, Maloni, and 
Carter (2009) posits that major businesses have selected to take part in the assured supply chain sustainability technique that aligns with their anticipated performance results. In spite of this arrangement, performance result on maintainable supply chain methods is still a puzzle. Additionally, assessing performance in sustainable supply chains remains in a comparatively early developing phase. Though numerous studies have been printed in this section, most of the work is theoretical in nature (Ashby, Leat, \& Hudson-Smith, 2012). Sustainability is gradually becoming a tactical firm initiative as both big and minor firms are recognizing that maintainable methods can be economical and might generate fresh income channels as likewise rise client and worker fulfillment Mincer (2008). Regardless of this, sustainability performance in an organization has attracted small study attention. Furthermore, as proposed by Ortas, Moneva, and Álvarez (2014) performance collected works lacks worldwide researches that measure the probable association amid sustainable supply chain technique and firm performance. However, several scholars have advocated that future studies should consider sustainability practices and organizational performance, through sustainability-oriented organizational culture and quality management-oriented organizational culture and reinforced by (Dessein et al., 2015).

According to Kataria, Kreiner, Hollensbe, Sheep, and Smith (2015) culture is viewed as a very complex phenomenon (Dubkevics \& Barbars, 2010) and it can take very broad, wide and multi-aspect dimensions. Organization culture can be viewed as a set of beliefs, values and shared assumptions in an organization. Hofstede (1998) states that culture should be posited in the minds of all members of an organization. Linnenluecke and Griffiths (2010) posit that numerous researchers propose that the pathway for the taking on of business sustainability values leads through the taking on of a sustainability-oriented organizational culture. Dessein et al. (2015) categorised culture and its association to sustainable development (SD) into three thematic clusters. (1) That culture has a helpful and self-promoting role. (2) Culture act as a frame, contextualize, mediate, and equilibrium the other 3 backbones of sustainability (i.e. "culture for maintainable growth'), which provides culture as a more influential power that can function over itself. Culture is a gobetween to link the numerous scopes of sustainability (Dessein et al., 2015) and (3) Incorporate, manage and direct all facets of maintainable action (i.e. 'culture as sustainable growth'), which perceives culture as the vital basis and component for attaining the sustainable growth objectives.

Thus, institutional culture can be a mediator or moderator. For mediation, Ogbonna and Harris (2000) argue that culture is a complete arbitrator (mediator) amid the leadership style and business performance. When considering the research by Harris and Ogbonna (2003) the institution culture might be a complete arbitrator also in the association amid the single/group leadership and consequences. In the meantime, culture is likewise an arbitrator amid the business plan and institution performance (Arogyaswamy \& Byles, 1987). Furthermore, green institutional culture is an arbitrator amid sustainability strengths and green innovation Küçükoğlu and Pınar (2015) and likewise, institution culture is an arbitrator in the association amid ecommerce espousal and hotel performance (Sobihah \& Lukman, 2015). Therefore, this study mediated organization culture on environmentally sustainable supply chain practices and performance of firms in Kenya.

\subsection{Hypothesis Development}

According to Marshall, McCarthy, McGrath, and Claudy (2015) environmental supply chain methods concentrate on resource utilization and effects on the physical surroundings. Whereas Green Supply Chain Management (GSCM) is well-defined by Dheeraj and Vishal (1992) as the technique of observing and enhancing environmental performance in the supply chain by incorporating environmental thinking into a supply chain management all over a products life cycle. For this study, environmental supply chain methods and green supply chain methods are used interchangeably. In the period of the late 1980 s and 1990s, the ideas of supply chain management and ecological as a strategic institutional practice to achieve competitive benefit has been getting amplified attention. Sarkis, Zhu, and Lai (2011) asserts that the importance of these strategic practices can be traced back to environmental management movement of the late 1960 s. Since then there has been a geometric growth in academic publications of this field (Fahimnia, Sarkis, \& Davarzani, 2015).

Green Environmental Supply Chain Management practices (GSCM) is the incorporation of ecological thinking into the supply chain which comprises of the industrial process, material finding and assortment, product design and supply of the ultimate produce to the customers as well as end-of-life managing of the merchandise after its useful life (Srivastava, 2007). Ecological facets of supply chain management have remained as the foremost concentration of study for the last 20 years as identified by Carter and Liane (2011). According to Das (2018) the logic behind regarding environmental management practices (EMP) as one of the significant issues affecting the performance of an institution can be drawn back to the outcomes of Hart (1995), Porter and Van der Linde (1995), Klassen and Whybark (1999), McLaughlin and Klassen (1996). Srivastava (2007) studied green supply chain management (GSCM) which he described as "study incorporating environmental rational in supply chain management, comprising product design, material obtaining, and assortment, manufacturing methods, supply of the ultimate product to the customers as well as finale of life management of the product after its beneficial life" (p. 54-55). He categorized researches into those regarding with the significance of GSCM, those concentrated on green design and those concerning green operations. 
Kleindorfer, Singhal, and Van Wassenhove (2005) studied researches of ecological sustainability in functions management issued in the initial fifty factors of Production and Operations Management (POM). The context that well-versed their appraisal demonstrates a lengthy supply chain embraced from Kleindorferr and Corbett (2001) and comprised in an article presenting the first exceptional factor of POM in regards to Environmental and Operations Management. Therefore, environmental supply chain methods can comprise any environmental exertion focused toward the formation, improvement, manufacture and/or distribution of a product to the final consumer.

Rands and Starik (1995) established that ecologically maintainable institutions will have institutional philosophies that emphasize the significance of environmental sustainability. Crane (2000) settled that an inflexible institutional philosophy can restrict the taking on of green practices. Likewise, Molnar and Mulvihill (2003) study exposed that "sustainability need to be incorporated into a company's culture, mission and dream”. In addition, Rands and Starik (1995) stressed that ecologically maintainable institutions need to nurture cultures originated on mutual ecological principles, sustainability behaviour customs, and artefacts which emphasize the significance of ecological sustainability.

Cranes and Harris (2002) who inspected the existence of green institutional philosophies in companies recognized that subcultures might hinder the growth of a company-wide green culture. From her case research of Grenville (2006) settled that a company's culture, and the existence of subcultures, establish which ecological matters it selects to tackle. Linnenlueckes, Russell, and Griffiths (2009) establish that subcultures in firms can influence on workers' level of comprehending sustainability inside their firm.

Narrowing the research to the influence of organization culture on performance indirectly through sustainability practices is not known as per the researcher knowledge on a review of the literature. Most studies on organization culture focus on adoption or implementation of sustainable practices and not on performance. Thus, the study hypothesized that:

$H_{I:}$ Environmentally sustainable supply chain practices positively improve performance via institution culture of manufacturing companies in Kenya.

\section{Theoretical Review}

The starting point of the resource-based view can be trailed back to previous study of Penrose (1959), Selznick (1957) amongst added scholars. The stress on this school of thinking was on the significance of assets and its effect for the company performance. This model basically stresses the notion that an institute need to be perceived as a package of resources and abilities to make worth and thus achieve a competitive benefit (Barney, 1991). The resource-based view in additional suggests that companies can attain general competitiveness and performance if they have touchable and untouchable assets that are valued, infrequent, unique and nonsubstitutable. These 4 features of assets refer to what Barleye (2007) think through as strategic resource that, if well-organized construct and sustain a company's competitive benefit and enhance its performance. Resource-Based View (RBV) offers a worthy hypothetical basis to deliberate the input of assets and aptitudes to a company's performance. The model provides an understanding into the associations amongst in-house resources, capabilities, and performance. The main impression of the RBV is that for a company to attain competitive benefit then it all relies on diverse resources, which are unique, valued and nonsubstitutable. It is maybe one of the most important frame-works in ecological management (Barney, 1991).

In accordance to Barney (1991) companies in the similar sector can be diverse in accordance to their personal assets and as resources are not flawlessly moveable amongst companies, the heterogeneity and the resultant competitive benefit attained might be long-lasting over time. Nevertheless, assets and abilities are not valued on their personal and are fundamentally fruitless in segregation (Newbert, 2008). As such, Newbert (2008) vies that the key to achieving a competitive gain is by the utilization of a valued resource ability combination. This view is in additional backed up by Ghobadian et al. (2007) who speak out that assets and abilities are bases of competitive gain, but they do not essentially input to competitive gain.

For companies to achieve competitive gain in this competitive surroundings, they need to offer worth to consumers. This worth can be derived from either cost benefit, service or distinguished merchandises. The resource-based model, thus, concentrates on the association amid a company's interior resource strength and the capability to remain competitive over its strategy preparation. Resource-based view model (RBV) has likewise remained lengthy by Grant (1991) to include competitive plan.

In respect to Grant (1991) Resource-based View Model connects competitive tactics and abilities to worth making. He suggests that not only do abilities require to be well thought-out as the foundation to advance a competitive plan but they likewise requires to be improved and upheld by the strategist. Hence RBV is significant to comprehend worth may stem from the strategic arrangement of resources and competitive tactics. In emerging their competitive tactics, the industrial companies in Kenya may give emphasis to the resources prevailing inside the company so as to be capable to make worth for its customers.

The resource-based theory of competitive benefit suggests that competitive gain may be maintained by yoking resources that are valued, infrequent, imperfectly imitable, and nonsubstitutable (Barney, 1991). Company's resources have remained well-defined as all assets, abilities, institutional procedures, company 
qualities, information, and knowledge organized by a company that empowers the company to look on and execute strategies with the aim to enhance its competence and effectiveness (competitiveness) (Barney, 1991; Daft, 1983). The extension of the resource-based view has comprised the incorporation of dynamic abilities (Helfat \& Peteraf, 2003) and natural resources (Hart, 1995). The growth of assets and abilities ought to be demonstrated via enhancements in numerous institutional performance measurements. For instance, a green initiative partnership with consumers was optimistically connected to value, elasticity, and ecological performance, whereas the partnership with contractors was linked with improved distribution performance (Klassen \& Vachon, 2006). Constructing these functional abilities through the greening of supply chains, in additional backs up the worth, infrequency, inimitability and nonsubstitutability characteristics of the RBV (Carteri et al., 1998; Foerstl, Reuter, Hartmann, \& Blome, 2010).

Researches and conceptualizations have establish and claimed for the enhancement of name and appearance, which is well thought-out as an important resource in general (Barney, 1991). Foerstl et al. (2010) posits that the values connected with greening the supply chain, the competitive gains are not essentially in the upstream (contractor management) phases of the supply chain as they might even be longer in the downstream (consumer) phases with green advertising abilities and resources (Shang, Lu, \& Li, 2010). RBV model helps to identify challenges in SSCM as identified by Touboulic and Walker (2015) as key challenges in SSCM is the proof of identity and growth of main resources giving to make sure attainment of ecological, community and economic performance in the supply chain.

Nevertheless, regardless of the amplified collected works dedicated to using of RBV, the model has its individual criticizers. According to Kalling and Hedman (2003) this model is condemned for disregarding the difficulties to changing aspects and management. Chan, He, and Wang (2004) likewise censure the model for its implied supposition of fixed balance yet competitive gains stem from growing present abilities that are extremely successful in answering to the institutional surroundings.

\section{Methodology}

This study embraced positivism paradigm while employing explanatory survey design. The target population of this study was supply chain managers from nine hundred and forty manufacturing firms in Kenya categorized into different regions. Using a sample of 281 respondents, a multistage sampling design was used to select sample respondents. At the final stage, a supply chain manager in each manufacturing firm was invited using purposive sampling to take part in the study. Data was collected using primary sources through structured questionnaires. The questionnaires were administered to the supply chain executives of the industrial firms in Kenya who are responsible for sustainable supply chain practices.

\subsection{Measurement of Variables}

Environmental sustainability practices measures was adapted from (Holt \& Rao, 2005; Vachon \& Mao, 2008; Vermeulen \& Ras, 2006; Zhu, Sarkis, \& Lai, 2007b; Zhuo \& Sarkis, 2004) Recycling of materials from Bouchery, Ghaffari, and Jemai (2010) and Toxic waste \& emission reduction from (Klassen \& Vachon, 2006; Matos \& Hall, 2007; Pappis \& Tsoulfas, 2006; Rao, 2002; Rogers \& Carter, 2008; Vachon, 2007; Vachon \& Klassen, 2003; Vachons \& Klassen, 2008; Zhu, Sarkis, \& Lai, 2007a).

On performance measures, the researcher adopted the questionnaire from Zailani, Jeyaraman, Vengadasan, and Premkumar (2012). who adopted it from Harmon and Cowan (2009) questionnaire model for measuring the performance of manufacturing firms in relation to sustainable supply chain practices. The researcher did not alter the questionnaire. The measures of institutional culture were adapted from an organizational culture assessment instrument (OCAI) and it's fixed in rival values framework (CVF) by Cameron and Quinn (2011).

\subsection{Structural Equation Modeling (SEM)}

The research used Partial Least Squares (PLS) of Structural Equation Modeling (SEM) to analyze the data. In accordance to Sorbom and Joreskog (2004) SEM has turn out to be a broadly used methodology for identifying, approximating and trying theorized associations amongst practically significant variables in the behavioural and communal sciences for the last two decades. The best method of (SEM) framework for trying indirect impacts is prejudice corrected bootstrapping, Bolger and Shrout (2002). As in all bootstrapping methods, BC bootstrapping of the confidence intervals (CIs) for indirect effects consist of taking numerous samples with replacement from the data set in question. SEM process follows two steps: authenticating the dimension model through carrying out confirmatory factor examination and appropriate the structural model through path analysis with latent variables using AMOS version 22. Kline (1998) proposed a two-step modeling process and needs SEM scholars to trial the untainted dimension model underlying a whole structural equation model, and if the fitting of the measurement model is found suitable, then the structural model is tested. 


\section{Finding and Discussions}

This chapter gives the analysis, presentation, interpretation, and discussion of results on the mediating effect of organization culture on environmentally sustainable supply chain practices and performance of industrial companies in Kenya.

\subsection{Descriptive Statistics, Reliability Validity and Correlation Analysis \\ 4.1.1. Environmentally Sustainable Supply Chain Practices}

Research respondents were asked to indicate on a five-point Likert scale their level of agreement on several statements describing environmentally sustainable supply chain practices as summarized in Table 1 . Table 1 depicts the mean, standard deviation, skewness and factor loadings of environmentally sustainable supply chain practices. Findings showed that all the statements representing environmental supply chain practices had a mean score of above 4.00, indicating that the respondents highly rated the variable. The overall skewness was -1.72 and kurtosis was 5.05 , indicating that the distribution of values deviates from the mean and are within the stipulated values of $<3$ for skewness and $<10$ for kurtosis as backed by Klinee (2005), Kline (2010) respectively. Similarly, the standard deviation of the majority of the items ranged between 0.75 and 1.4. It could then be deduced that the responses to the environmental supply chain practices items were not deviating much from the expected responses. From the 6 statements used to explain environmental supply chain sustainable practices had an overall mean score of 4.36 indicating that respondents agreed on environmental supply chain practices measures. This shows that majority of the respondents agreed with the statements that were used to measure environmental supply chain practices.

Table-1. Environmentally sustainable supply chain practices.

\begin{tabular}{|c|c|c|c|c|}
\hline Survey item & Mean & Std. deviation & Skewness & Loadings \\
\hline $\begin{array}{l}\text { Our organization procures recycled materials which } \\
\text { are then used in our day to day operations }\end{array}$ & 4.03 & 1.398 & -1.247 & 0.884 \\
\hline $\begin{array}{l}\text { We often ask suppliers to commit to waste } \\
\text { reduction goals set by our organization }\end{array}$ & 4.35 & 0.85 & -1.784 & 0.85 \\
\hline $\begin{array}{l}\text { Our organization is involved in cleaner production } \\
\text { which is a core value in our internal policies }\end{array}$ & 4.48 & 0.754 & -1.871 & 0.842 \\
\hline $\begin{array}{l}\text { The organization I work for participates in the } \\
\text { design of products that are energy efficient. }\end{array}$ & 4.42 & 0.795 & -1.594 & 0.537 \\
\hline $\begin{array}{l}\text { We often tailor our products to meet both pollution } \\
\text { and emission minimization }\end{array}$ & 4.48 & 0.765 & -2.023 & 0.517 \\
\hline $\begin{array}{l}\text { Our organization has an effective environmental } \\
\text { management system in place which guides all our } \\
\text { environment-related issues }\end{array}$ & 4.39 & 0.751 & -1.777 & 0.873 \\
\hline Environmental supply chain practices & 4.3582 & 0.58607 & -1.716 & \\
\hline
\end{tabular}

\subsection{Organization Culture}

Respondents were tasked with the responsibility of responding on the statements related to organisation culture as indicated in Table 2 . Table 2 shows the mean, standard deviation, skewness and loadings of each item representing organisation culture. From the results, all the statements representing organization culture had a mean score of above 4.00, indicating that the respondents highly rated the variable. The overall skewness was -1.02 and kurtosis was 1.38, indicating that the distribution of values deviates from the mean and it is within the recommended values of $<3$ for skewness and $<10$ for kurtosis respectively (Klinee, 2005) From the 8 statements used to explaining organization culture had an overall mean score of 4.37 indicating that respondents agreed on organization culture measures. These shows that most of the respondents settled with the declarations that were in use to quantify institutional culture. Institutional culture teaches the population about the achievement of the purposes inside the institute. These findings concur with Ahmad, Veerapandian, and Ghee (2011) that a key to better performance is a robust culture, an important and robust culture can create an institute to attain outstanding performance, whereas adverse and feeble culture might result to low performances and at the finale no attainment.

\subsection{Performance of Manufacturing Firms}

Research respondents were inquired to indicate on a five-point Likert scale their level of agreement on several statements relating to performance of manufacturing firms as summarized in Table 3.The standard deviation of performance of manufacturing firms ranged between 0.66 and 0.84 . It could then be deduced that the responses to the performance of a manufacturing firm's items were not deviating much from the expected responses. All the statements representing the performance of manufacturing firms had a mean score of above 4.38 , indicating that the respondents highly rated the variable. The overall skewness was -1.57 and kurtosis 
was 2.85 , indicating that the distribution of values deviates from the mean and this is within the recommended threshold of $<3$ for skewness and $<10$ for kurtosis respectively (Kline, 2010; Klinee, 2005). From the 10 statements used to explain the performance of manufacturing firms had an overall mean score of 4.38 indicating that respondents agreed on the performance of a manufacturing firm's measures. This shows that majority of the respondents agreed with the statements that were used to measure the performance of manufacturing firms.

\begin{tabular}{|c|c|c|c|c|}
\hline Survey item & Mean & Std. deviation & Skewness & Loadings \\
\hline $\begin{array}{l}\text { Our organization procures recycled } \\
\text { materials which are then used in our day to } \\
\text { day operations }\end{array}$ & 4.03 & 1.398 & -1.247 & 0.884 \\
\hline $\begin{array}{l}\text { We often ask suppliers to commit to waste } \\
\text { reduction goals set by our organization }\end{array}$ & 4.35 & 0.85 & -1.784 & 0.85 \\
\hline $\begin{array}{l}\text { Our organization is involved in cleaner } \\
\text { production which is a core value in our } \\
\text { internal policies }\end{array}$ & 4.48 & 0.754 & -1.871 & 0.842 \\
\hline $\begin{array}{l}\text { The organization I work for participates in } \\
\text { the design of products that are energy } \\
\text { efficient. }\end{array}$ & 4.42 & 0.795 & -1.594 & 0.537 \\
\hline $\begin{array}{l}\text { We often tailor our products to meet both } \\
\text { pollution and emission minimization }\end{array}$ & 4.48 & 0.765 & -2.023 & 0.517 \\
\hline $\begin{array}{l}\text { Our organization has an effective } \\
\text { environmental management system in place } \\
\text { which guides all our environment-related } \\
\text { issues }\end{array}$ & 4.39 & 0.751 & -1.777 & 0.873 \\
\hline Environmental supply chain practices & 4.3582 & 0.58607 & -1.716 & \\
\hline
\end{tabular}

Table-3. Performance of manufacturing firms.

\begin{tabular}{|c|c|c|c|c|}
\hline Survey items & Mean & Std. deviation & Skewness & Loadings \\
\hline $\begin{array}{l}\text { In our firm, we have recorded significant } \\
\text { improvement in terms of sales and market } \\
\text { share }\end{array}$ & 4.56 & 0.69 & -1.52 & 1.772 \\
\hline $\begin{array}{l}\text { In our firm, there has been an improvement in } \\
\text { the image of our organization and products }\end{array}$ & 4.44 & 0.658 & -1.052 & 1.16 \\
\hline $\begin{array}{l}\text { We have also seen some significant } \\
\text { improvement in relations with community } \\
\text { stakeholders such as Non-governmental } \\
\text { organizations and community activists }\end{array}$ & 4.22 & 0.828 & -1.19 & 1.963 \\
\hline $\begin{array}{l}\text { Our organization has achieved significant } \\
\text { improvement in compliance with } \\
\text { environmental standards. }\end{array}$ & 4.32 & 0.796 & -1.654 & 4.184 \\
\hline $\begin{array}{l}\text { We have also recorded a significant reduction } \\
\text { in consumption of hazardous materials and } \\
\text { energy }\end{array}$ & 4.44 & 0.715 & -1.239 & 1.808 \\
\hline $\begin{array}{l}\text { In our firm, we have been able to reduce } \\
\text { manufacturing and operational costs. }\end{array}$ & 4.29 & 0.775 & -1.058 & 1.284 \\
\hline $\begin{array}{l}\text { The has also been a reduction in the number } \\
\text { of days for a supply chain to respond to plan, } \\
\text { source, make and deliver unexpected demand } \\
\text { variations }\end{array}$ & 4.3 & 0.786 & -0.921 & 0.519 \\
\hline Overall mean & 4.3789 & 0.47944 & -1.565 & \\
\hline
\end{tabular}

$\mathrm{KMO}=0.870,(\mathrm{df}=15)$, total variance explained $(51.826)$

Bartlett's Test of Sphericity .000 AVE $=0.519, \mathrm{CR}=0.881$, Cronbach's alpha $=.840$

\subsection{Hypotheses Testing for Mediation of Organisation Culture on Environmentally Supply Chain Practices and Firm Performance}

In this research, SEM was in use to carry out arbitration examinations by means of AMOS version 22.

The study hypothesis is stated as below: 
$H_{1}$ : Environmentally sustainable supply chain practices improve the performance of manufacturing firm via organization culture.

The study tests the mediating effect of organization culture on the relationship between environmentally sustainable supply chain practices and performance of manufacturing companies in Kenya. The findings are depicted in Figure 1, Table 4 and Table 5 respectively. Figure 1, shows the structural model for environmentally sustainable supply chain practices, organisation culture and performance of manufacturing firms in Kenya. Table 4 displays estimates of relationships between environmentally sustainable supply chain practices, organisation culture and performance with their p-values and Table 5 depicts bias corrected bootstrapping results of direct, indirect and total effects of study variables.

The effect of environmentally sustainable supply chain practices on the performance of manufacturing firms, the direct effect is .259 (the path coefficient from ecological supply chain practices to performance of manufacturing firms) as shown in Figure 1 and Table 4. The indirect effect, through organization culture, is computed as the product of the path coefficient from environmentally maintainable supply chain carry outs to the organisation culture and the path coefficient from organization culture to performance $\left(1.144^{*} .605=.692\right)$ as depicted in Table 5 .

The aggregate effect is the summation of direct and indirect effects $(.259+.692=.951)$ as portrayed in Table 5. From the results the indirect effect $\left(1.144^{*} .605=.692\right)$, is higher than the direct effect of .259. Thus, the study concludes that the construct organization culture is a mediator in the relationship between environmentally sustainable supply chain practices and performance of manufacturing firms. The type of mediation is full mediation since the direct effect is not significant when the mediator was introduced in the model. The researcher, therefore, concludes that there is a complete mediation effect between organization culture on environmentally sustainable supply chain practices and performance of manufacturing firms hence this model attains steps and guidelines suggested by Hair, Black, Babin, Anderson, and Tatham (2006); Preacher and Hayes (2008) and Metters, Zhao, Bendoly, Jiang, and Young (2010). The study, therefore, fails to rejects hypothesis $\mathrm{H}_{1}$ and infers that organization culture variable fully mediates the relationship between environmentally sustainable supply chain practices on the performance of manufacturing firms. This shows that the higher the organization culture in manufacturing firms, environmentally sustainable supply chain practices will highly increase the performance of the firms. This is supported by Fernández, Junquera, and Ordiz (2003) argument that excellent environmental performance depends upon incorporating environmental issues into the organizational culture. In support of this finding, Miska, Hilbe, and Mayer (2014) postulated that companies in cultures with greater future orientation practices are more likely to engage in economic sustainability practices. Cognate to this finding, in regard to future orientation culture, Bansal and Ortiz (2016) display that companies that take part in maintainable longer-term carry outs have lesser financial instability, greater sales increase, and greater probabilities of continued existence. This agrees to Ashkanasy, Gupta, Mayfield, and Trevor-Roberts (2004) classification of cultures with greater future orientation as bearing in mind materialistic attainment and spiritual satisfaction to be incorporated and assigning a greater importance on long-term achievement, and it bring into line with the idea of sustainability inside the economic sphere. It is thus probable that firms in cultures with better future orientation carry outs are more probable to take part in ecologically sustainable carry outs that lead to improved performance.

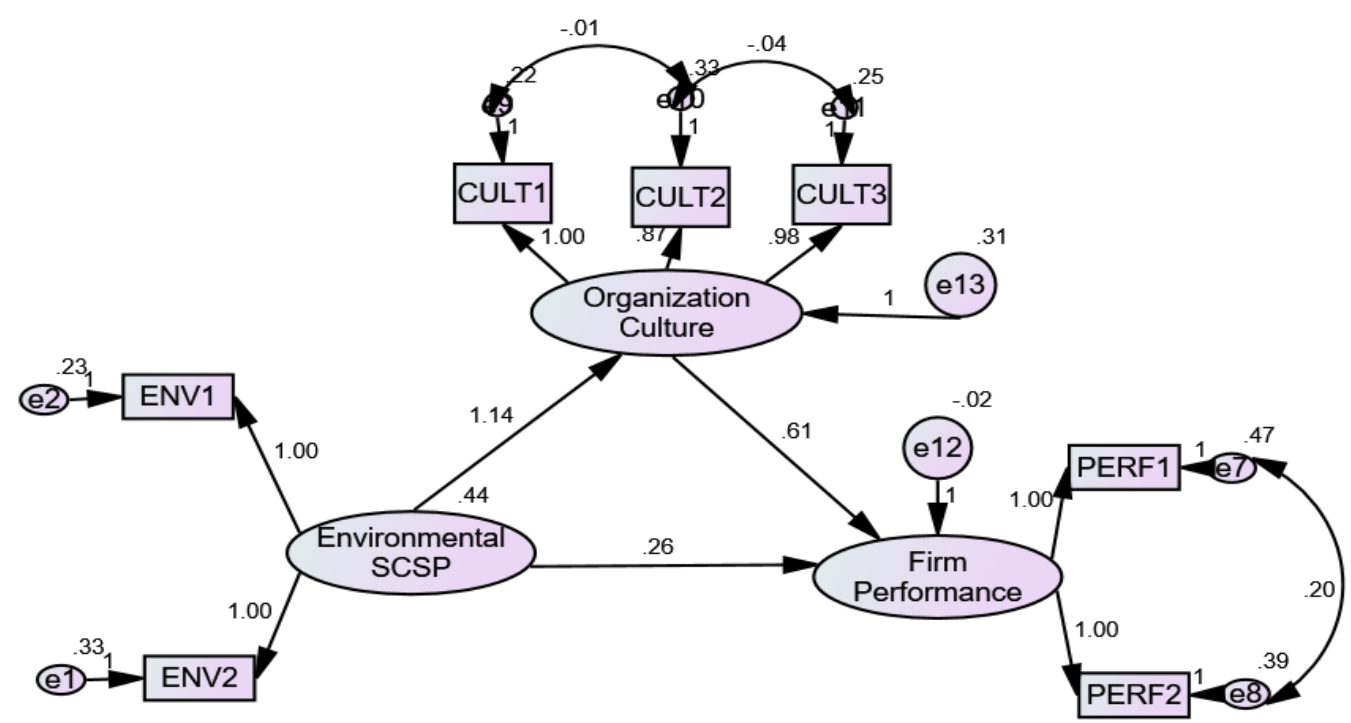

Figure-1. SEM model for mediating effect of organisation culture on environmental SSCP and firm performance. 
Table-4. SEM results for mediating effect of organization culture on environmental SSCP and firm performance.

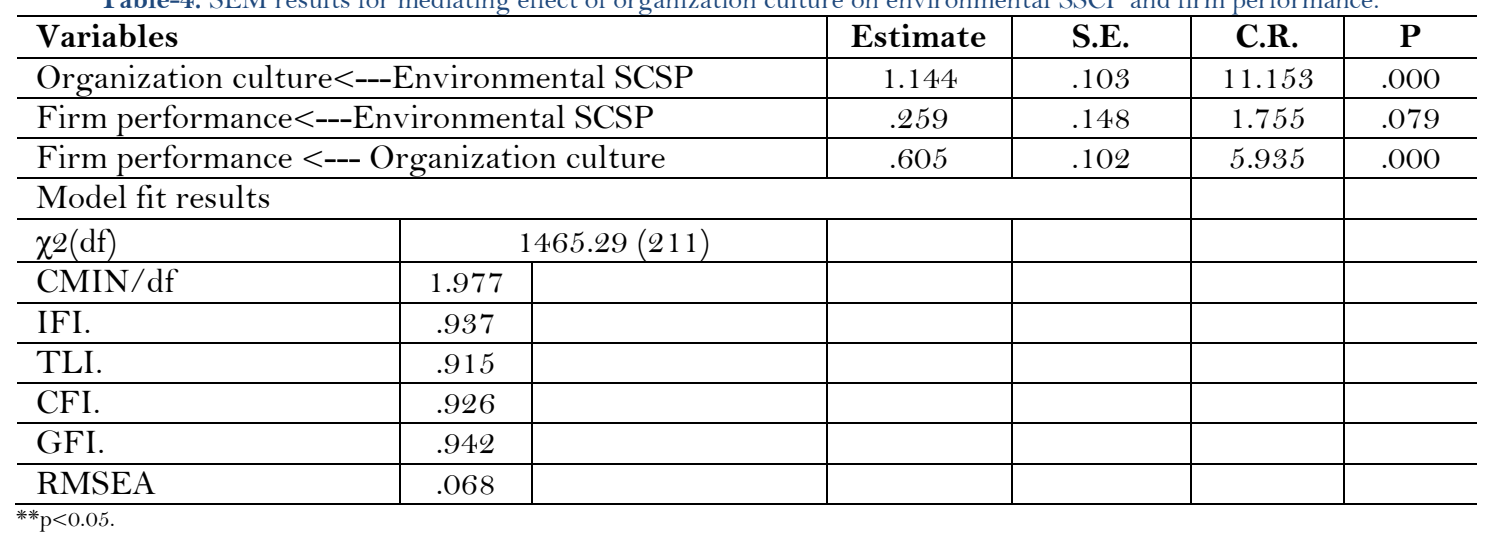

Table-5. Total effect, direct effect and indirect effect of organization culture on environmental SSCP and firm performance.

\begin{tabular}{c|c|c|c|c}
\hline Effects & Variables & $\begin{array}{c}\text { Environmental } \\
\text { SCSP }\end{array}$ & $\begin{array}{c}\text { Organization } \\
\text { culture }\end{array}$ & $\begin{array}{c}\text { Firm } \\
\text { performance }\end{array}$ \\
\hline Total effect & Organization culture & 1.144 & .000 & .000 \\
\hline & Firm performance & .951 & .605 & .000 \\
\hline Direct effect & Organization culture & 1.144 & .000 & .000 \\
\hline & Firm performance & .259 & .605 & .000 \\
\hline Indirect effect & Organization culture & .000 & .000 & .000 \\
\hline & Firm performance & .692 & .000 & .000 \\
\hline
\end{tabular}

\section{Conclusions and Recommendations}

This study provides empirical support that organization culture mediates the relationship between environmentally sustainable supply chain practices on the performance of manufacturing firms in Kenya. The organization culture variable fully mediates the relationship between environmentally sustainable supply chain practices and performance of manufacturing firms. The more the organization culture developed in manufacturing firms the higher the environmental supply chain practices influences the performance of the firms. The role of organizational culture in improving the performance of manufacturing firms through environmental supply chain practices should not be neglected. The manufacturing firm should pay attention to fostering a strong organization culture geared towards sustainability if they seek to gain from sustainable supply chain practices implemented. In conclusion, the key issues in organization culture the manufacturing firms should focus on are; the manufacturing firm should be results-oriented with the main concern is getting the job done, eventually making employees competitive and achievement-oriented. The leadership of the manufacturing firm also plays a fundamental role in the culture of the firm. The leader should exemplify coordinating, organizing and efficiency among employees. To sum up, when manufacturing firms adopt all these organization cultural practices, they are able to implement environmentally sustainable supply chain practices effortlessly and in that way increase their performance.

\subsection{Contribution of Study to Knowledge}

There is flimsy evidence of studies examining the mediation effect of organization culture on environmentally sustainable supply chain practices and performance of manufacturing firms. This study, therefore, filled the knowledge gap that was established by Dahlgaard-Park et al. (2015) and Dessein et al. (2015) by providing evidence of complete mediation effect of organization culture on environmentally sustainable supply chain practices. Under the RBV theory, growth of resources and abilities might be demonstrated through enhancements in numerous institutional performance dimensions. For instance, a green initiative partnership with consumers was optimistically connected to quality, elasticity, and ecological performance, whereas the partnership with contractors was related with improved distribution performance (Klassen \& Vachon, 2006). Construction these functioning abilities through the greening of supply chains in additional backs up the worth, infrequency, inimitability, and non-substitutability aspects of the RBV (Carteri et al., 1998; Foerstl et al., 2010). Maintainable supply chain carry outs influence performances of manufacturing companies and also economically maintainable supply chain practices predict the performance of manufacturing firms (Marshall et al., 2015).

\subsection{Contribution of the Study to Profession and Managerial Implication}

Practical implications are quite apparent in this study. Supply chain managers, production managers or operations managers in the manufacturing sector need to establish how best they can foster an organizational culture that supports supply chain sustainability practices in their organization. A strong organizational 
culture geared towards sustainability in the organization leads to the enhanced implementation of sustainable supply chain practices in the organization which in turn increases the performance of firms.

\subsection{Managerial and Policy Implication}

The supply chain managers of manufacturing firms should ensure that environmentally sustainable supply chain practices such as recycling of materials, adoption of cleaner production methods, enhanced pollution and emission prevention measures, production of products that are energy-efficient, adoption of environmental management systems and commitment to waste reduction are put in place to enhance the environmental performance of manufacturing firms. The supply chain managers of manufacturing firms should build an organizational culture with environmental supply chain practices in mind. From the past studies on sustainability initiatives and organization culture, it shows that culture does matter incorporate sustainability success. The managers of manufacturing firms should build an organizational culture with environmental concerns in all their processes. The manufacturing firms' managers should provide clear organization leadership, provide the organization glue that holds the organization together and provide dominant characteristics such as competitiveness that provide criteria for the success of sustainability issues.

Future studies should establish the mediating effect of organization culture on sustainable supply chain practices and performance of firms in the service sectors and draw comparisons between manufacturing sectors and service sectors. In addition, the link between sustainable supply chain practices and organizational culture in terms of research is still scanty and grey. Researchers should further research on the role of organizational culture in promoting the success of sustainability initiatives of firms and also analyze if organizations can demonstrate a unified organizational culture that bases its values and beliefs on sustainable supply chain practices and improvement of firm's performance.

\section{References}

Ahi, P., \& Searcy, C. (2015). An analysis of metrics used to measure performance in green and sustainable supply chains. Journal of Cleaner Production, 86, 360-377. Available at: https://doi.org/10.1016/j.jclepro.2014.08.005.

Ahmad, K. Z., Veerapandian, K. A., \& Ghee, W. Y. (2011). Person-environment fit: The missing link in the organisational culture-commitment relationship. International Journal of Business and Management, 6(11), 11. Available at: https://doi.org/10.5539/ijbm.v6n 11 p 11 .

Arogyaswamy, B., \& Byles, C. M. (1987). Organizational culture: Internal and external fits. Journal of Management, 13(4), 647-658. Available at: https://doi.org/10.1177/014920638701300406.

Ashby, A., Leat, M., \& Hudson-Smith, M. (2012). Making connections: A review of supply chain management and sustainability literature. Supply Chain Management: An International Journal, 17(5), 497-516. Available at: https://doi.org/10.1108/13598541211258573.

Ashkanasy, N. M., Gupta, V., Mayfield, M. S., \& Trevor-Roberts, E. (2004). Future orientation. Culture, leadership and organizations: The GLOBE study of 62 societies (pp. 282-342). Thousand Oaks, CA, USA: Sage Publications.

Bansal, P., \& Ortiz, d. M., N. (2016). The long-term benefits of organizational resilience through sustainable business practices. Strategic Management Journal, 37(8), 1615-1631.

Barleye, S. R. (2007). Corporations, democracy, and the public good. Journal of Management Inquiry, 16(3), $201-215$. Available at: https://doi.org/10.1177/1056492607305891.

Barney, J. (1991). Firm resources and sustained competitive advantage. Journal of Management, 17(1), 99-120. Available at: https://doi.org/10.1177/014920639101700108.

Bolger, N., \& Shrout, P. E. (2002). Mediation in experimental and nonexperimental studies: New procedures and recommendations. Psychological Methods, 7(4), 422-445. Available at: https://doi.org/10.1037/1082-989x.7.4.422.

Bouchery, Y., Ghaffari, A., \& Jemai, Z. (2010). Key performance indicators for sustainable distribution supply chains: Set building methodology and application. Research Papers, 8, 37-56.

Cameron, K. S., \& Quinn, R. E. (2011). Diagnosing and changing organizational culture: Based on the competing values framework: John Wiley \& Sons.

Carter, C. R., \& Liane, E. P. (2011). Sustainable supply chain management: Evolution and future directions. International Journal of Physical Distribution \& Logistics Management, 41(1), 46-62.

Carteri, C. S., Braver, T. S., Barch, D. M., Botvinick, M. M., Noll, D., \& Cohen, J. D. (1998). Anterior cingulate cortex, error detection, and the online monitoring of performance. Science, 280(5364), 747-749. Available at: https://doi.org/10.1126/science.280.5364.747.

Chan, H. K., He, H., \& Wang, W. Y. (2004). Green marketing and its impact on supply chain management in industrial markets. Industrial Marketing Management, 41(4), 557-562. Available at: https://doi.org/10.1016/j.indmarman.2012.04.002.

Crane, A. (2000). Facing the backlash: Green marketing and strategic reorientation in the 1990s. Journal of Strategic Marketing, 8(3), 277-296.

Cranes, A., \& Harris, L. C. (2002). The greening of organizational culture: Management views on the depth, degree and diffusion of change. Journal of Organizational Change Management, 15(3), 214-234. Available at: https://doi.org/10.1108/09534810210429273.

Daft, R. L. (1983). Learning the craft of organizational research. Academy of Management Review, 8(4), 539-546. Available at: https://doi.org/10.2307/258255.

Dahlgaard-Park, S. M., Jens, J., Dahlgaard, P., Maletic, M., Maletic, D., Dahlgaard, J., . . . Gomišcek, B. (2015). Do corporate sustainability practices enhance organizational economic performance? International Journal of Quality and Service Sciences, 7(2/3), 184-200. 
Das, D. (2018). Sustainable supply chain management in Indian organisations: An empirical investigation. International Journal of Production Research, 56(17), 5776-5794.

Dessein, J., Soini, K., Fairclough, G., Horlings, L., Battaglini, E., Birkeland, I., \& Mihailova, M. (2015). Culture in, for and as sustainable development: Conclusions from the COST Action IS1007 Investigating Cultural Sustainability: University of Jyvaskyla.

Dheeraj, N., \& Vishal, N. (1992). An overview of green supply chain management in India. Research Journal of Recent Sciences.

Dubkevics, L., \& Barbars, A. (2010). The role of organizational culture in human resource management. Human Resources Management and Ergonomics, 4(1), 25-35.

Fahimnia, B., Sarkis, J., \& Davarzani, H. (2015). Green supply chain management: A review and bibliometric analysis. International Journal of Production Economics, 162, 101-114.

Fernández, E., Junquera, B., \& Ordiz, M. (2003). Organizational culture and human resources in the environmental issue: A review of the literature. International Journal of Human Resource Management, 14(4), 634-656.

Foerstl, K., Reuter, C., Hartmann, E., \& Blome, C. (2010). Managing supplier sustainability risks in a dynamically changing environment-Sustainable supplier management in the Chemical industry. Journal of Purchasing and Supply Management, 16(2), 118-130.

Ghobadian, A., O'Regan, N., Howard, T., Gallear, D., Bitar, J., \& Hafsi, T. (2007). Strategizing through the capability lens: Sources and outcomes of integration. Management Decision, 45(3), 403-419.

Grant, R. M. (1991). The resource-based theory of competitive advantage: Implications for strategy formulation. California Management Review, 33(3), 114-135. Available at: https://doi.org/10.2307/41166664.

Grenville, H.-J. A. (2006). Inside the "black box" how organizational culture and subcultures inform interpretations and actions on environmental issues. Organization \& Environment, 19(1), 46-73. Available at: https://doi.org/10.1177/1086026605285739.

Hair, J. F., Black, W. C., Babin, B. J., Anderson, R. E., \& Tatham, R. L. (2006). Multivariate data analysis. 6.

Harmon, R. R., \& Cowan, K. R. (2009). A multiple perspectives view of the market case for green energy. Technological Forecasting and Social Change, 76(1), 204-213.

Harris, L. C., \& Ogbonna, E. (2003). The organization of marketing: A study of decentralized, devolved and dispersed marketing activity. Journal of Management Studies, 4O(2), 483-512. Available at: https://doi.org/10.1111/14676486.00348 .

Hart, O. (1995). Corporate governance: Some theory and implications. The Economic Journal, 105(430), 678-689. Available at: https://doi.org/10.2307/2235027.

Helfat, C. E., \& Peteraf, M. A. (2003). The dynamic resource-based view: Capability lifecycles. Strategic Management Journal, 24(10), 997-1010.

Hofstede, G. (1998). Attitudes, values and organizational culture: Disentangling the concepts. Organization Studies, 19(3), 477-493.

Holt, D., \& Rao, P. (2005). Do green supply chains lead to competitiveness and economic performance? International Journal of Operations \& Production Management, 25(9), 898-916.

Kalling, T., \& Hedman, J. (2003). The business model concept: Theoretical underpinnings and empirical illustrations. European Journal of Information Systems, 12(1), 49-59. Available at: https://doi.org/10.1057/palgrave.ejis.3000446.

Kataria, N., Kreiner, G. E., Hollensbe, E., Sheep, M. L., \& Smith, B. R. (2015). Elasticity and the dialectic tensions of organizational identity: How can we hold together while we are pulling apart? Academy of Management Journal, 58(4), 981-1011. Available at: https://doi.org/10.5465/amj.2012.0462.

Klassen, R. D., \& Vachon, S. (2006). Extending green practices across the supply chain: The impact of upstream and downstream integration. International Journal of Operations \& Production Management, 26(7), 795-821.

Klassen, R. D., \& Whybark, D. C. (1999). The impact of environmental technologies on manufacturing performance. Academy of Management Journal, 42(6), 599-615. Available at: https://doi.org/10.5465/256982.

Kleindorfer, P. R., Singhal, K., \& Van Wassenhove, L. N. (2005). Sustainable operations management. Production and Operations Management, 14(4), 482-492.

Kleindorferr, P. R., \& Corbett, C. J. (2001). Environmental management and operations management: Introduction to part 1 (manufacturing and ecologistics). Production and Operations Management, 10(2), 107-111.

Kline, R. B. (1998). Principles and practice of structural equation modeling. New York: Guilford.

Kline, R. B. (2010). Promise and pitfalls of structural equation modeling in gifted research. In B. Thompson \& R. F. Subotnik (Eds.), Methodologies for conducting research on giftedness (pp. 147-169). Washington, DC, US: American Psychological Association.

Klinee, R. B. (2005). Principles and practice of structural equation modeling (2nd ed.). New York: Guilford.

Küçükoğlu, M. T., \& Pınar, R. İ. (2015). Positive influences of green innovation on company performance. Procedia-Social and Behavioral Sciences, 195, 1232-1237.

Linnenluecke, M., \& Griffiths, A. (2010). Beyond adaptation: Resilience for business in light of climate change and weather extremes. Business \& Society, 49(3), 477-511.

Linnenlueckes, M. K., Russell, S. V., \& Griffiths, A. (2009). Subcultures and sustainability practices: The impact on understanding corporate sustainability. Business Strategy and the Environment, 18(7), 432-452.

Marshall, D., McCarthy, L., McGrath, P., \& Claudy, M. (2015). Going above and beyond: How sustainability culture and entrepreneurial orientation drive social sustainability supply chain practice adoption. Supply Chain Management: An International Journal, 20(4), 434-454.

Matos, S., \& Hall, J. (2007). Integrating sustainable development in the supply chain: The case of life cycle assessment in oil and gas and agricultural biotechnology. Journal of Operations Management, 25(6), 1083-1 102. Available at: https://doi.org/10.1016/j.jom.2007.01.013. 
McLaughlin, C. P., \& Klassen, R. D. (1996). The impact of environmental management on firm performance. Management Science, 42(8), 1199-1214. Available at: https://doi.org/10.1287/mnsc.42.8.1199.

Metters, R., Zhao, X., Bendoly, E., Jiang, B., \& Young, S. (2010). The way that can be told of is not an unvarying way: Cultural impacts on Operations Management in Asia.

Mincer, J. (2008). The color of money: sustainability has become more than a buzzword among corporations. It has become smart business. Wall Street Journal.

Miska, C., Hilbe, C., \& Mayer, S. (2014). Reconciling different views on responsible leadership: A rationality-based approach. Journal of Business Ethics, 125(2), 349-360. Available at: https://doi.org/10.1007/s 1055 1-013-1923-8.

Molnar, E., \& Mulvihill, P. R. (2003). Sustainability-focused organizational learning: Recent experiences and new challenges. Journal of Environmental Planning and Management, 46(2), 167-176. Available at: https://doi.org/10.1080/0964056032000070990.

Naslund, D., \& Williamson, S. (2010). What is management in supply chain management? A critical review of definitions, frameworks and terminology. Journal of Management Policy and Practice, 11(4), 11-28.

Newbert, S. L. (2008). Value, rareness, competitive advantage, and performance: A conceptual-level empirical investigation of the resource-based view of the firm. Strategic Management Journal, 29(7), 745-768. Available at: https://doi.org/10.1002/smj.686.

Ogbonna, E., \& Harris, L. C. (2000). Leadership style, organizational culture and performance: Empirical evidence from UK companies. International Journal of Human Resource Management, 11(4), 766-788. Available at: https://doi.org/10.1080/09585190050075114.

Ortas, E., Moneva, J. M., \& Álvarez, I. (2014). Sustainable supply chain and company performance: A global examination. Supply Chain Management: An International Journal, 19(3), 332-350. Available at: https://doi.org/10.1 108/scm-122013-0444.

Pappis, C. P., \& Tsoulfas, G. T. (2006). Environmental principles applicable to supply chains design and operation. Journal of Cleaner Production, 14(18), 1593-1602. Available at: https://doi.org/10.1016/j.jclepro.2005.05.021.

Penrose, E. (1959). The theory of the growth of the firm. New York: John Wiley\& Sons.

Porter, M., \& Van der Linde, C. (1995). Green and competitive: Ending the stalemate. The Dynamics of the eco-efficient economy: Environmental regulation and competitive advantage. 33.

Preacher, K. J., \& Hayes, A. F. (2008). Asymptotic and resampling strategies for assessing and comparing indirect effects in multiple mediator models. Behavior Research Methods, 4O(3), 879-891.

Pullman, M. E., Maloni, M. J., \& Carter, C. R. (2009). Food for thought: Social versus environmental sustainability practices and performance outcomes. Journal of Supply Chain Management, 45(4), 38-54. Available at: https://doi.org/10.1111/j.1745-493x.2009.03175.x.

Rands, G. P., \& Starik, M. (1995). Weaving an integrated web: Multilevel and multisystem perspectives of ecologically sustainable organizations. Academy of Management Review, 20(4), 908-935. Available at: https://doi.org/10.2307/258960.

Rao, P. (2002). Greening the supply chain: A new initiative in South East Asia. International Journal of Operations E Production Management, 22(6), 632-655. Available at: https://doi.org/10.1 108/014435702 10427668.

Rogers, D. S., \& Carter, C. R. (2008). A framework of sustainable supply chain management: Moving toward new theory. International Journal of Physical Distribution $\Theta^{\circ}$ Logistics Management, 38(5), 360-387. Available at: https://doi.org/10.1108/09600030810882816.

Sarkis, J., Zhu, Q., \& Lai, K.-h. (2011). An organizational theoretic review of green supply chain management literature. International Journal of Production Economics, 130(1), 1-15. Available at: https://doi.org/10.1016/j.ijpe.2010.11.010.

Selznick, P. (1957). Leadership in administration. Berkeley: University of California Press.USA.

Shang, K.-C., Lu, C.-S., \& Li, S. (2010). A taxonomy of green supply chain management capability among electronicsrelated manufacturing firms in Taiwan. Journal of Environmental Management, 91(5), 1218-1226.

Sobihah, A. M., \& Lukman, Z. (2015). Organizational culture mediate between E-Commerce adoption and hotel performance. Mediterranean Journal of Social Sciences, 6(2), 61-66.

Sorbom, D., \& Joreskog, K. G. (2004). LISREL 8.71 [Computer software]. Chicago, IL: Scientific Software International.

Srivastava, S. K. (2007). Green supply chain management: A state of the art literature review. International Journal of Management Reviews, 9(1), 53-80.

Touboulic, A., \& Walker, H. (2015). Love me, love me not: A nuanced view on collaboration in sustainable supply chains. Journal of Purchasing and Supply Management, 21(3), 178-191. Available at: https://doi.org/10.1016/j.pursup.2015.05.001.

Vachon, S. (2007). Green supply chain practices and the selection of environmental technologies. International Journal of Production Research, 45(18-19), 4357-4379. Available at: https://doi.org/10.1080/00207540701440303.

Vachon, S., \& Klassen, R. D. (2003). Collaboration and evaluation in the supply chain: The impact on plant-level environmental investment. Production and Operations Management, 12(3), 336-352. Available at: https://doi.org/10.1111/j.1937-5956.2003.tb00207.x.

Vachon, S., \& Mao, Z. (2008). Linking supply chain strength to sustainable development: A country-level analysis. Journal of Cleaner Production, 16(15), 1552-1560. Available at: https://doi.org/10.1016/j.jclepro.2008.04.012.

Vachons, S., \& Klassen, R. D. (2008). Environmental management and manufacturing performance: The role of collaboration in the supply chain. International Journal of Production Economics, 111(2), 299-315. Available at: https://doi.org/10.1016/j.ijpe.2006.11.030.

Vermeulen, W. J., \& Ras, P. (2006). The challenge of greening global product chains: Meeting both ends. Sustainable Development, 14(4), 245-256.

Zailani, S., Jeyaraman, K., Vengadasan, G., \& Premkumar, R. (2012). Sustainable supply chain management (SSCM) in Malaysia: A survey. International Journal of Production Economics, 14O(1), 330-340. 
Zhu, Q., Sarkis, J., \& Lai, K. H. (2007a). Green supply chain management implications for "closing the loop. Transportation Research Part E: Logistics and Transportation Review, 44(1), 1-18.

Zhu, Q., Sarkis, J., \& Lai, K. H. (2007b). Confirmation of a measurement model for green supply chain management practices implementation. International Journal of Production Economics, 11 1(2), 261-273.

Zhuo, Q., \& Sarkis, J. (2004). Relationships between operational practices and performance among early adopters of green supply chain management practices in Chinese manufacturing enterprises. Journal of Operations Management, 22(3), 265-289. Available at: https://doi.org/10.1016/s0272-6963(04)00039-7. 